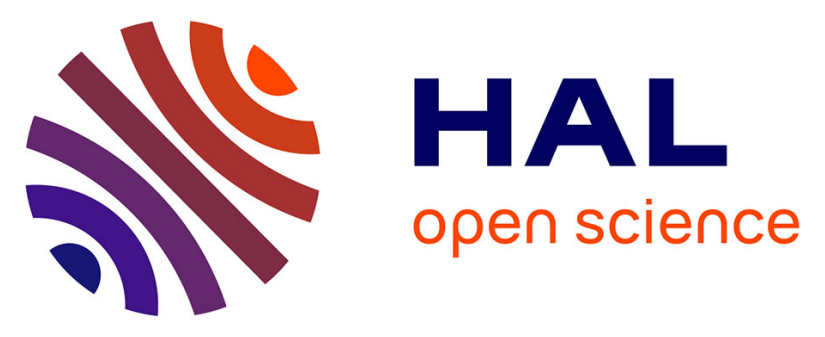

\title{
Who are the PLWH who might refuse to participate in HIV cure-related clinical trials with treatment interruption?
}

\author{
Christel Protière, Marion Fiorentino, Abdourahmane Sow, Marie Préau, \\ Marion Mora, Lisa Fressard, Laurence Meyer, Jean-Daniel Lelièvre, Olivier \\ Lambotte, Bruno Spire, et al.
}

\section{To cite this version:}

Christel Protière, Marion Fiorentino, Abdourahmane Sow, Marie Préau, Marion Mora, et al.. Who are the PLWH who might refuse to participate in HIV cure-related clinical trials with treatment interruption?. AIDS. Official journal of the international AIDS Society, 2020, pp.1. 10.1097/QAD.0000000000002530 . hal-02547988

\section{HAL Id: hal-02547988 \\ https://hal-amu.archives-ouvertes.fr/hal-02547988}

Submitted on 18 May 2021

HAL is a multi-disciplinary open access archive for the deposit and dissemination of scientific research documents, whether they are published or not. The documents may come from teaching and research institutions in France or abroad, or from public or private research centers.
L'archive ouverte pluridisciplinaire HAL, est destinée au dépôt et à la diffusion de documents scientifiques de niveau recherche, publiés ou non, émanant des établissements d'enseignement et de recherche français ou étrangers, des laboratoires publics ou privés.

\section{(ㄷ)(1) $\$$}

Distributed under a Creative Commons Attribution - NonCommerciall 4.0 International 
Who are the persons living with HIV who might refuse to participate in HIV cure-related clinical trials with treatment interruption?

Christel Protiere $^{\mathrm{a}, \mathrm{b}}$, Marion Fiorentino ${ }^{\mathrm{a}, \mathrm{b}}$, Abdourahmane Sow $^{\mathrm{a}, \mathrm{b}}$, Marie Préauc, Marion Mora ${ }^{\mathrm{a}, \mathrm{b}}$, Lisa Fressard ${ }^{\mathrm{b}, \mathrm{d}, \mathrm{e}}$, Laurence Meyer ${ }^{f}$, Jean-Daniel Lelièvre ${ }^{g, h, i}$, Olivier Lambotte $^{, k, l, m}$, Bruno Spire $^{a, b}$ and Marie Suzan-Monti ${ }^{a, b}$

Achieving a HIV cure has become a research priority. As any improvement of knowledge, which could help scientists design new HIV cure-related clinical trials (HCRCT) depends on the risks potential participants are willing to accept, it is important to understand who will agree or refuse to participate and in which proportions. By providing insights into factors associated with reluctance toward HCRCT participation, our results may help clinicians in patient recruitment.

Achieving a HIV cure has become a research priority, implying the need for HIV cure-related clinical trials (HCRCT) with analytical antiretroviral treatment interruption (ATI) [1-13]. In the current context of modern, well tolerated, combined antiretroviral therapy (cART), clinical and biological HCRCT-related issues cannot be disconnected from associated ethical questions or from the consequences on the daily lives of persons living with HIV (PLWH) who will participate in HCRCT [14-26]. As any improvement in knowledge regarding future HCRCT depends on the risks that potential participants 
are willing to accept, it is important not only to document their preferences for different candidate HCRCT types but also to acquire a greater understanding about which PLWH would be more likely to agree or to refuse to participate, and in which proportions [15,26-29].

The ANRS-APSEC study (Acceptability, expectations and preferences for HCRCT among PLWH with undetectable viral load and caregivers) [27,29,30] produced new knowledge regarding this issue.

Between October 2016 and March 2017, all PLWH who had a scheduled follow-up consultation during a dedicated week meeting HCRCT eligibility criteria $(\geq 18$ years old, stable ART regimen $\geq 6$ months, undetectable viral load $\geq 3$ years, and $\mathrm{CD}^{+}$ $>500$ cells $/ \mu \mathrm{l}$ ) were surveyed in 19 French HIV services. One questionnaire (detailed in [26]) section presented PLWH with four viewpoints (elicited elsewhere [27]), from the most motivated to the most reluctant vis-à-vis participation in HCRCTwith ATI. PLWH were asked to rate, on a 7-point Likert scale, to what degree each of the four viewpoints reflected their opinion.

To construct the dependent variable, we performed a principal component analysis of their answers, creating a 'reluctance score' to represent their level of willingness to participate in HCRCT (from -5.46 very motivated, to +6.51 very reluctant). The higher the score, the more reluctant respondents were to participate.
The reluctance score allowed us to infer the proportion of respondents that would be motivated (score $<25$ th percentile) or reluctant ( $>75$ th percentile) to participate and to compare these proportions with those obtained when we used the usual direct question found in the literature 'If an HCRCT were available, would you participate in it? ('Absolutely not', 'Probably not', 'Yes, perhaps', 'Yes, definitely')'.

We performed a multivariable linear regression to determine factors associated with reluctance to participate in HCRCT.

All 195 PLWH presented to the interviewers agreed to participate. Women constituted $23.58 \%$ of the sample, median [IQR] age was 53 [45-61] years, and median experience with HIV was 17 [11-25] years.

Intention to participate in HCRCT using the direct question was distributed as follows: $42.56 \%$ responded 'Yes, definitely', 37.95\% 'Yes, perhaps', 10.78\% 'Probably not', and $8.72 \%$ 'Absolutely not'. More nuanced replies were obtained when inferred from the reluctance score (Fig. 1).

On the basis of the reluctance score, a lower percentage of PLWH would be motivated to participate in HCRCT (26.67\%) than the $42.56 \%$ who answered 'Yes, definitely' to the direct question. In contrast, a larger percentage of PLWH would be reluctant to participate $(21.03 \%)$ than the $8.72 \%$ who answered 'Absolutely not'.

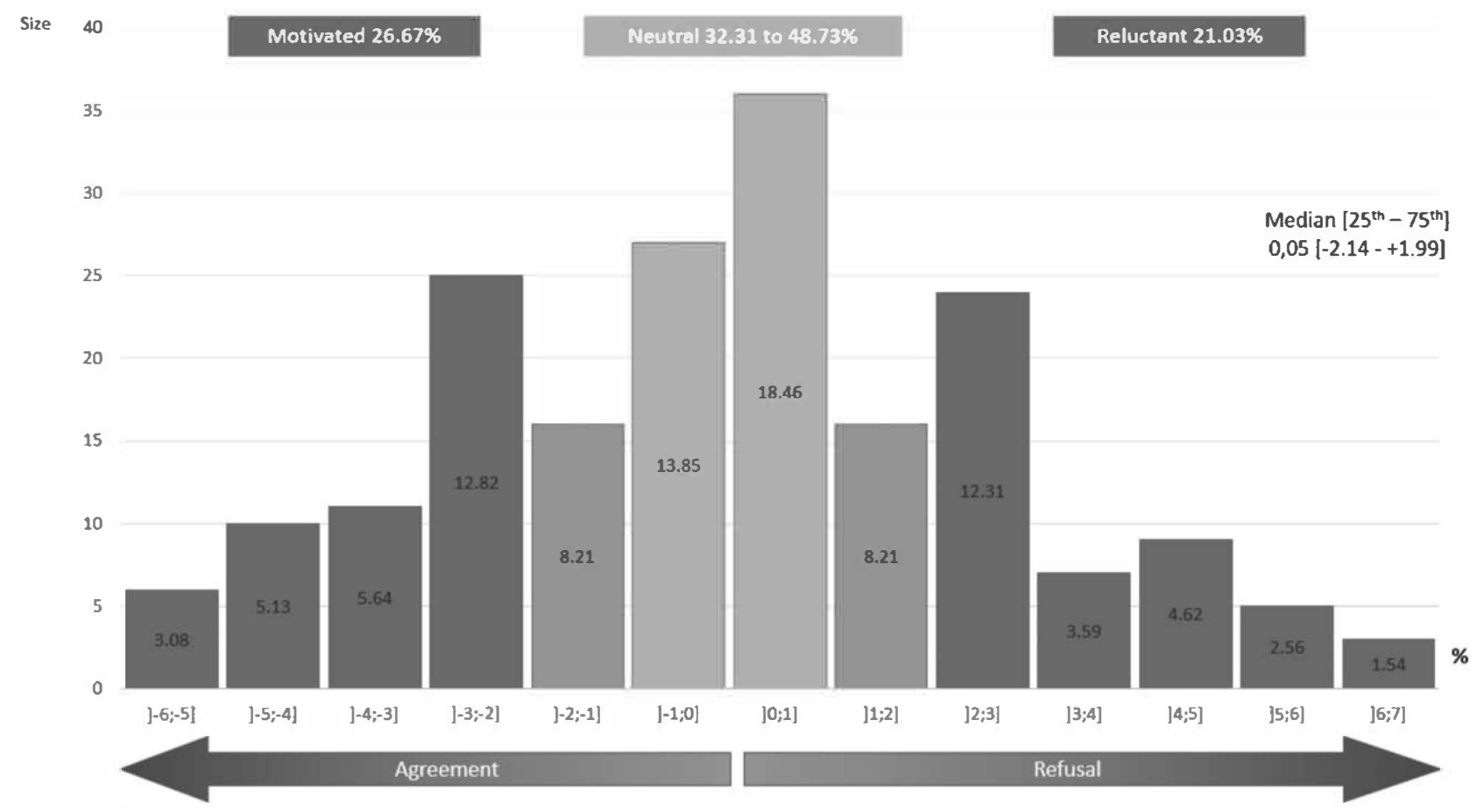

Fig. 1. Distribution of respondents according to the reluctance score $(n=195)$. 
The final best-fit model showed that PLWH who reported a precarious financial situation $(\beta=0.863$, $P=0.027)$, those with the highest $(\beta=1.220$, $P=0.015)$ educational levels, those with the lowest $(\beta=1.399, P=0.005)$ educational levels, and those who thought that current ART would continue to be effective only in the short/medium term (versus long term) $(\beta=1.548, P=0.006)$ would all be more reluctant to participate in HCRCT. In contrast, patients who selfidentified as belonging to the PLWH community $(\beta=-1.031, P=0.014)$, and those a little or very concerned about the risk of HIV transmission $(\beta=-0.895, P=0.091 ; \beta=-1.231, P=0.005)$ would be less reluctant, and thus more motivated to participate.

Gender, being a homeowner, professional status, selfperceived health-state, self-identifying as belonging to the LGBT community, being an HIV activist, and feeling proud or self-confident, were no longer significant.

Some of these results deserve special attention. First, financially precarious PLWH may anticipate difficulties regarding hospital visits in terms of time and economic burden. Second, the association between reluctance and both low and high educational levels reflects findings regarding vaccination hesitancy in the general population [31-34]. This result can be explained on the one hand by a lack of information about prevention strategies and on the other hand by misinformation and mistaken beliefs relayed by (social) media [32,35-38]. Third, the association between a lack of confidence in the long-term efficacy of cARTand reluctance to participate may seem counter-intuitive, but this factor might have captured a more general lack of confidence in the healthcare system, including HCRCT efficiency $[33,39]$. Finally, in line with previous surveys underlying that PLWH motivations to participate were more altruistic than individualistic $[18,20,26,27,30]$, the results showed that PLWH concerned about the risk of HIV transmission would be more motivated to participate in HCRCT, hoping they could put an end to transmission.

Using the novel approach of examining PLWH level of agreement with different viewpoints, instead of using the usual direct question, in order to document their willingness to participate in HCRCT, our results, despite being declarative, may better reflect real-world decisionmaking, and may partly overcome the issue of social desirability bias $[40,41]$. Declared willingness to participate in HCRCT may have been overestimated in previous quantitative studies $[15,22,27,28]$ as suggested by qualitative surveys $[16,42,43,20,29]$. Knowing the proportion of PLWH who would agree to participate is important for physicians when designing new HCRCT. Moreover, providing insights into factors associated with reluctance to participate in HCRCT may help clinicians in HCRCT recruitment and inform them of potential selection bias. Greater attention should be paid to the burden associated with hospital visits for treatment and examinations, particularly during ATI, as well as the need to provide clear information to counter mistaken beliefs about future HCRCT.

Finally, our results emphasize the need to consider not only clinical characteristics, but also social and identity characteristics when implementing HCRCT. They also underline the importance of actively involving PLWH in discussions about the goals of HIV cure research $[2,19]$.

\section{Acknowledgements}

We are grateful to all the participants, PLWH and members of the following centers:

Aix en Provence (Centre Hospitalier Général, Pr A.P. Blanc); Avignon (Centre Hospitalier Henri Duffaut, Dr G. Lepeu); Bordeaux (Hôpital Pellegrin, Pr J.M. Ragnaud; Hôpital Saint André, Pr P. Morlat); Créteil (Hôpital Intercommunal, Dr I. De Lacroix; Hôpital Henri Mondor, Pr J.D. Lelièvre); Dijon (Hôpital Du Bocage, Pr L. Piroth); Kremlin-Bicêtre (Hôpital Bicêtre, Pr C. Goujard); Lyon (Hôpital Edouard Herriot, Pr J.L. Touraine; Hôpital De La Croix Rousse, Pr D. Peyramond); Marseille (Hôpital Ste-Marguerite, $\operatorname{Pr}$ I. Poizot-Martin); Nantes (Hôpital Hôtel-Dieu, Pr F. Raffi); Paris (Hôpital Saint Antoine, Pr P.M. Girard; Hôpital Pompidou, Pr L. Weiss; Hôpital Saint Louis, Pr J.M. Molina; Hôpital Bichat, Pr Y. Yazdanpanh; G. H. Pitié Salpêtrière, Pr C. Katlama; Hôpital Lariboisière, $\operatorname{Pr}$ J.F. Bergmann; Hôtel Dieu, Pr J. Blacher), Rennes (CHRU Pontchaillou, Pr C. Michelet); Suresnes (Hôpital Foch, Dr D. Zucman); Toulon (Hôpital Sainte Musse, Dr A. Lafeuillade); Toulouse (Hôpital Purpan, Pr P. Delobel); Tourcoing (Hôpital Gustave Dron, Pr E. Senneville).

We thank the members of the APSEC scientific committee for their advice: J. Barbot, F. Barré-Sinoussi, A. Chéret, P. Delobel, V. Doré, S. Fainzang, C. Gasiglia, C. Gauzente, J. Ghosn, C. Goujard, O. Lambotte, J.-D. Lelièvre, A. Mennecier, L. Meyer, M. Mora, M. Préau, C. Protière, A. L. Ross, C. Rouzioux, B. Spire, M. Suzan-Monti.

We also thank the SESSTIM-ORS PACA logistic platform: G. Maradan, F. Prestigiacomo, E. Parizi. Finally, our thanks to Jude Sweeney for revising and editing the English version of the manuscript.

ANRS-APSEC study group: Pr J.F. Bergmann, Pr J. Blacher, Pr A.P. Blanc, Pr P. Delobel, Pr P.M. Girard, Pr C. Goujard, Pr C. Katlama, Dr I. De Lacroix, Dr A. Lafeuillade, PrJ.D. Lelièvre, Dr G. Lepeu, Pr C. Michelet, 
Pr J.M. Molina, Pr P. Morlat, Pr D. Peyramond, Pr L. Piroth, Pr I. Poizot-Martin, Pr F. Raffi, Pr J.M. Ragnaud, Pr E. Senneville, Pr L. Weiss, Pr Y. Yazdanpanh, Dr D. Zucman.

Author's contributions: C.P., M.P., M.M., O.L., B.S., M.S.M. designed the study; C.P., A.S., L.F. conducted the analyses; all authors contributed to article writing and review.

Grant: The ANRS-APSEC survey was supported by a grant (convention number 14697) from ANRS (France Recherche Nord \& sud Sida-hiv Hépatites).

\section{Conflicts of interest}

There are no conflicts of interest.

${ }^{a}$ Aix Marseille Univ, INSERM, IRD, SESSTIM, Sciences Economiques \& Sociales de la Santé \& Traitement de I'Information Médicale, Marseille, France; ${ }^{b} \mathrm{ORS}$ PACA, Observatoire régional de la santé ProvenceAlpes-Côte d'Azur, Marseille, France; ${ }^{C} G R e P S$ Lyon 2 Université, Bron, France; ${ }^{d}$ Aix Marseille Univ, IRD, APHM, SSA, VITROME, Marseille, France; 'IHUMéditerranée Infection, Marseille, France; IINSERM, U1018, Université Paris-Sud 11, AP-HP, Hôpital de Bicêtre, Département d'épidémiologie, Le KremlinBicêtre, France; 'INSERM, U955, Equipe 16, Créteil, France; ' Université Paris Est, Faculté de médecine, France; 'Vaccine Research Institute, Créteil, 94000, France; 'Assistance Publique - Hôpitaux de Paris, Hôpital Bicêtre, Service de Médecine Interne et Immunologie clinique, Le Kremlin-Bicêtre, France; ${ }^{k}$ INSERM, U1184, Immunology of Viral Infections and Autoimmune Diseases, Le Kremlin-Bicêtre, France; 'Université Paris Sud, UMR 1184, Le Kremlin-Bicêtre, France; and ${ }^{m} C E A$, DSV/IMETI, IDMIT, Fontenay-auxRoses, France.

Correspondence to Christel Protiere, Aix Marseille Univ - SESSTIM, 19-21 Bd Jean Moulin, 13005 Marseille, France. Tel: +33 413732 286; e-mail: christel.protiere@inserm.fr

Received: 4 November 2019; accepted: 18 March 2020.

\section{References}

1. Sáez-Cirión A, Bacchus $C$, Hocqueloux L, Avettand-Fenoel V, Girault I, Lecuroux C, et al. Post-treatment HIV-1 controllers with a long-term virological remission after the interruption of early initiated antiretroviral therapy ANRS VISCONTI Study. PLoS Pathog 2013; 9:e1003211.

2. Julg B, Dee L, Ananworanich J, Barouch DH, Bar K, Caskey M, et al. Recommendations for analytical antiretroviral treatment interruptions in HIV research trials-report of a consensus meeting. Lancet HIV 2019; 6:e259-e268.

3. Palich R, Ghosn J, Chaillon A, Boilet V, Nere M-L, Chaix M-L, et al., VRI02/ANRS149 LIGHT Vaccine Trial Group. Viral rebound in semen after antiretroviral treatment interruption in an HIV therapeutic vaccine double-blind trial. AIDS 2019; 33:279-284.
4. Ghosn J, Palich R, Chaillon A, Boilet V, Nere M, Delobel P, et al., VRI02/ANRS149 LIGHT Vaccine Trial Group. Viral rebound in semen after treatment interruption in a HIV therapeutic vaccine double-blind trial (VRI02/ANRS149-LIGHT). J Int AIDS Soc 2017; 20:279-284.

5. Lévy Y, Leliévre J-D, Perrier A, Boilet V, Bouchaud O, Girard P$M$, et al. Preliminary Safety Results from the VRI02 ANRS 149 Light (Lipopeptide and DNA GTU HIV Therapeutic Trial). AIDS Res Hum Retroviruses 2016; 32:406.

6. Ghosn J, Delaugerre C. Can we avoid treatment interruption studies in the search for an HIV cure. AIDS 2015; 29:15751577.

7. Tucker JD, Rennie S, The Social and Ethical Working Group on HIV Cure. Social and ethical implications of HIV cure research. AIDS 2014; 28:1247-1250.

8. Chun T-W, Eisinger RW, Fauci AS. Durable control of HIV infection in the absence of antiretroviral therapy: opportunities and obstacles. JAMA 2019; 322:27-28.

9. Bar-On Y, Gruell H, Schoofs T, Pai JA, Nogueira L, Butler AL, et al. Safety and antiviral activity of combination HIV-1 broadly neutralizing antibodies in viremic individuals. Nat Med 2018; 24:1701-1707.

10. Fromentin R, DaFonseca S, Costiniuk CT, El-Far M, Procopio FA, Hecht FM, et al. PD-1 blockade potentiates HIV latency reversal ex vivo in CD4+ $T$ cells from ART-suppressed individuals. Nat Commun 2019; 10:814.

11. Uldrick TS, Gonçalves PH, Abdul-Hay M, Claeys AJ, Emu B Ernstoff MS, et al., Cancer Immunotherapy Trials Network (CITN)-12 Study Team. Assessment of the safety of pembrolizumab in patients with HIV and advanced cancer - a phase 1 study. JAMA Oncol 2019; 5:1332-1339.

12. Halper-Stromberg A, Lu C-L, Klein F, Horwitz JA, Bournazos $S$ Nogueira $L$, et al. Broadly neutralizing antibodies and viral inducers decrease rebound from HIV-1 latent reservoirs in humanized mice. Cell 2014; 158:989-999.

13. Xu L, Wang J, Liu Y, Xie L, Su B, Mou D, et al. CRISPR-edited stem cells in a patient with hiv and acute lymphocytic leukemia. N Engl J Med 2019; 381:1240-1247.

14. Barré-Sinoussi F, Ross AL, Delfraissy J-F. Past, present and future: 30 years of HIV research. Nat Rev Microbiol 2013; 11:877-883.

15. Arnold MP, Evans D, Vergel N. Recruitment and ethical considerations in HIV cure trials requiring treatment interruption. J Virus Erad 2015; 1:43-48.

16. Chu CE, Wu F, He X, Ma Q, Cheng Y, Cai W, et al. Exploring the social meaning of curing HIV: a qualitative study of people who inject drugs in Guangzhou, China. AIDS Res Hum Retroviruses 2015; 31:78-84.

17. Kuritzkes DR. Why cure, why now? J Med Ethics 2017; 43:6770.

18. Protière $C$, Préau $M$, Doumergue $M$, Mora $M$, Lambotte $O$, Spire $B$, et al. Will CURE trials introduce an uncomfortable revolution in the field of HIV research? HIV Clin Trials 2017; 18:1-2.

19. Protière $C$, Préau $M$, Carrieri $P$, Lambotte $O$, Spire $B$, SuzanMonti $\mathrm{M}$. Importance of the patient-physician interaction in assessing acceptability of HIV cure trials. HIV Med 2017; 19:e56-e57.

20. Dube K, Evans D, Dee L, Sylla L, Taylor J, Skinner A, et al. 'We Need to Deploy Them Very Thoughtfully and Carefully': perceptions of analytical treatment interruptions in hiv cure research in the united states-a qualitative inquiry. AIDS Res Hum Retroviruses 2017; 34:67-79.

21. Ethics of treatment interruption trials in HIV cure research: addressing the conundrum of risk/benefit assessment . J Med Ethics. [cited 2017 Nov 28]. Available at: http://jme.bmj. com/content/early/201 7/11/10/medethics-2017-104433. long.

22. Simmons R, Kall M, Collins S, Cairns G, Taylor S, Nelson M, et al. A global survey of HIV-positive people's attitudes towards cure research. HIV Med 2017; 18:73-79.

23. Kumar R. Contractualist reasoning, HIV cure clinical trials, and the moral (ir)relevance of the risk/benefit ratio. J Med Ethics 2017; 43:124-127.

24. Buchak L. Why high-risk, nonexpected-utility-maximising gambles can be rational and beneficial: the case of HIV cure studies. J Med Ethics 2017; 43:90-95. 
25. Jones RB. Current challenges and recent advances in the search for a cure for HIV. J Int AIDS SOC 2019; 22:e25248.

26. Protiere C, Arnold MP, Fiorentino M, Fressard L, Lelievre J-D, Mimi $M$, et al. Differences in HIV cure clinical trial preferences of French people living with HIV and physicians in the ANRSAPSEC study. A discrete choice experiment. J Int AIDS SOC 2020; 23:e25443.

27. Protière $C$, Spire $B$, Mora $M$, Poizot-Martin I, Préau $M$, Doumergue $M$, et al. Patterns of patient and healthcare provider viewpoints regarding participation in HIV cure-related clinical trials. Findings from a multicentre French survey using Q methodology (ANRS-APSEC). PLoS One 2017; 12:e0187489.

28. Dubé K, Evans D, Sylla L, Taylor J, Weiner BJ, Skinner A, et al. Willingness to participate and take risks in HIV cure research: survey results from $\mathbf{4 0 0}$ people living with HIV in the US. J Virus Erad 2017; 3:40-50.

29. Preau M, Doumergue M, Protiere C, Goujard C, Mora M, Meyer $L$, et al. Acceptability of HIV cure-related trials: the challenges for physicians and people living with HIV (ANRS-APSEC). AIDS Care 2018; 30:914-920.

30. Fiorentino M, Protière C, Sagaon-Teyssier L, Mimi M, Fressard L, Arnold MP, et al. What is the effect of self-identified HIV activism in willingness to participate in HIV cure-related clinical trials? Results from the ANRS-APSEC study. I Virus Erad 2019; 5:152-162.

31. Larson HJ, Jarrett C, Eckersberger E, Smith DMD, Paterson P. Understanding vaccine hesitancy around vaccines and vaccination from a global perspective: a systematic review of published literature. Vaccine 2014; 32:2150-2159.

32. Peretti-Watel P, Larson HJ, Ward JK, Schulz WS, Verger P. Vaccine Hesitancy: Clarifying a Theoretical Framework for an Ambiguous Notion. PLOS Curr 2015pii: ecurrents.outbreaks.6844c80ff9f5b273f34c91f71b7fc289.

33. Kumar $D$, Chandra R, Mathur M, Samdariya $S$, Kapoor N. Vaccine hesitancy: understanding better to address better. Isr J Health Policy Res 2016; 5:2.
34. Detoc M, Launay O, Dualé C, Mutter C, Le Huec J-C, Lenzi N, et al. Barriers and motivations for participation in preventive vaccine clinical trials: Experience of 5 clinical research sites. Vaccine 2019; 37:6633-6639.

35. Dubé E, Laberge C, Guay M, Bramadat $P$, Roy R, Bettinger J. Vaccine hesitancy: an overview. Hum Vaccines Immunother 2013; 9:1763-1773.

36. Rey D, Fressard L, Cortaredona S, Bocquier A, Gautier A, Peretti-Watel $\mathrm{P}$, et al. Vaccine hesitancy in the French population in 2016, and its association with vaccine uptake and perceived vaccine risk-benefit balance. Euro Surveill 2018; 23:17-00816.

37. Broadbent JJ. Vaccine hesitancy: misinformation on social media. BMJ 2019; 66:I4457.

38. Verger $P$, Bocquier $A$, Vergélys $C$, Ward J, Peretti-Watel P. Flu vaccination among patients with diabetes: motives, perceptions, trust, and risk culture - a qualitative survey. $B M C$ Public Health 2018; 18:569.

39. Protière C, Donaldson C, Moatti JP, Luchini S, Shackley P. The impact of information on nonhealth attributes on willingness to pay for multiple healthcare programmes. Soc Sci Med 2004; 58:1257-1269.

40. van de Mortel T. Faking it: social desirability response bias in self-report research. Aust J Adv Nurs 2008; 25:40-48.

41. Edwards AL. The relationship between the judged desirability of a trait and the probability that the trait will be endorsed. J. Appl Psychol 1953; 37:90-93.

42. Ma Q, Wu F, Henderson G, Rennie S, Rich ZC, Cheng Y, et al. ' can coexist with HIV': a qualitative study of perceptions of HIV cure among people living with HIV in Guangzhou, China. Virus Erad 2016; 2:170-174.

43. Moodley K, Staunton C, de Roubaix M, Cotton M. HIV cure research in South Africa: a preliminary exploration of stakeholder perspectives. Aids Care-Psychol Socio-Med Asp AidsHiv 2016; 28:524-527.

DOI:10.1097/QAD.0000000000002530 